ture. After the peritoneal toilet has been completed a pocket is made by blunt dissection between the peritoneun and the under surface of
the rectus musele, on either one or both sides of the ineision, necording
to the number of grafts to be 1 . to the ntmber of grafts to be used. The ovaries are then earefully remainder is ent into disks 2 egeneration are culled out af ter whieh the lisks transplanted into the already used to loold tlie grufts in place. The prepared poekets. No sntures are the usial manner.

Radiation Versus Surgery in the Treatment of Uterine Cancer.The working rnles that lave heen adopted Jy Crossen (Jour. Mfissouri Stale Mcd. Assn., 1922, 19, 5il) are that in the advanced inoperable cases as well as in the borderline eases of uterine concer, rullimn is our inost effeetive reinerly. The palliative effeet is nothing short of wonderful. The cularged careinomatous eervix with its hlecling papillarymasses melts away as if by anagic and tle cavity eloses, lnrgely or entirel. by granulation. IBnt it should be renemberel that rudimm is two-edged and may do as much harm by cansing cxcessive sear tissne contraction or actual stimulntion of the eaneer eells as it may do good, consepnently

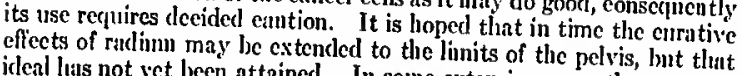
ideal las not yet been attrined. In some extensive eases the enneer is completely elinninated ly the radimm; this result is nttnined. however, in
anly a small proportion of the enses. It may be hoped for but it is so infrequent in thic classes of eases under consideration that the remed! wuist be presented to the patient as essentially a palliative measure, with ouly a possihility of cure. It is advisable to cmploy also derp roentgen-ray therapy to affect the eancer cells lying beyoul the effective reach of the radium, Init even this combination inust lic elassel generally as pallintive rather than eurutive. In eleurly operable cases, that is, in
those early eases apparently still eonfined to the uterns, Crossen feels
that immediate removal of the uteris and that immediate removal of the uterus and aljacent tissue likely to be involved is the safest plan. Theoretieally we should be able to cure these patients with radiun witl as grent certainty und with fur less limger than with the knjfe; but so far the netual results in caneer of the uterus do not justify displacement of the knife by radiun in tliese enrly cases. In something over one thousand eollected eases of earcinomi of the cervix treated hy radium five years previons to the reports, about 20 per cent were eured-approximately the same percentige us hy radieal operation. When the eases were divided into elasses it was found that more of the advaneed and borderline eases were enrerl by radinu than by operation, while of the early operable enses the percentage of cures hy radium (31 per eent) fell deeidedly below that by operation (40 to 45 per eent). We know what cun lie done with the knife in the individual case but we lo not know the extent of the effectiveness of radium in an indiviclual case until it is tried in thent case and in the time required for trial by radium the ehance of cure by operation slips away. In order to give the patient the best ehance of ene in these early cases, it is advisabie to employ both radiun and operation. First give a leavy dose of radium, the same as though depending on it to effect a eure, then within a weck or ten days do the 
radieal operation. 'The operation should be earried out within a short time after the rachium treatment beenuse latel the radium treatment may have caused such marked conneetive tissue changes as to increasc very decidedly the difficnlties nnd lazard of the operition. 'This plan of treatinent for the carly ease is based on the assumption that the patient is a good operative risk. If the patient has some serions complieation making her a poor operative risk, then her best chince of survival cenneer-free may be through radimn withont operation. 'The clecision for or against operation and of the extent of operation, turns on a balaneing of the hazards pro and cou-the hazard of operation, the ehance of faihnre of radinm to kill the eaneer eells in that individnitl, ind the chimce of metastasis near nnd far. On acconnt of the litter dimger, it is advisable to supplement the other treatment by decp roentgr'n-rily treatment.

Urethral Stricture in Women.-Stricture of the urethril in women is a condition which is very often overlooked, aecording to SrEvens (Cal. Stetc.Jour. Merl., 1922, 20,51) nlthough it may be responsible for marked functional and organic disturbances in the genito-urinary tract in this sex. It is a generally necepted iclea that strietures of the female uretlira are very uncommon. While this is true so fur as the lmuen of the canal is coneerned, strietures at the mentus on the other hand are frecunently encauntererl. As the female bladder is especially sensitive to rellex influenees, marked subjective symptoms are of ten prodheed by eompurutively slight obstructions. It innst be remembered however, that these symptoms inu' be partly due to the aeeonpanying urethritis or trigonitis. Frecunent uriuntion is the most comnon simptom of which these patients complain. The next most eomuon symptom is pain which is referred to the urethrnl or blalder regions. The dingnosis is best made by means of the olive-tipped bougie. The majority of these strietures should be treated by means of gradual dilatation, absorption of the eonstricting exudate heing best pronoted by this procedure. In the presence of sear tissue however, meatotony, internal urethrotomy: or exterual Irethrotony with resection of the sear tissue is olten inclicated. The sy'mptoms improve, as a rule after two and disappear after five dilatations, recurrenee being very unusnal if treatment is not too abruptly discontinued.

This snbject hats also been cnrefully presented by Wrinse (Siurg. Gynce. and Ohst., 1922, 34, 208), who stittes that the great majority of strietures are siugle, althongh multiple ones hive been reported; and althongh the stricture may be located in any part of the urcthra, the external meat 1 s and nnterior portion are the fivorite sites. He classifies strictnres as traumatic, inflanmatory, neoplastie, congenital, senile and unknown, which terms are self-explanatory. The onset is nsually gradnal und the course progressive. In some eases the only symptoms noted by the patient are the small strean voided und the length of tinne reruired for the act of voiding, but in the great majority of eases there is nlso some clegree of dysuria. The dingnosis is made by exanination with sonnds or, preferably, olive-tipped or bulbed bongies as alvised above by Stevens. In eertain eases the strietured area ein be felt through the vagina. The endoseope is necessary for a complete examination. Wynne treats these patients by gradual dilatition of the 
strieture with sounds, bougies, or Hegar dilators over a consideralls le period of time. This operation is carried out nfter a local anestletic has been applied to the urethral mueous membrane. The dilating instrunents slould be generously lubrieated before insertion and the largest instrunent passed at auy sitting shonld be left in place for from ten to fifteen ininutes. The size of the dilators used must be determined eueh time by the degree of pain eassed. It is necessary to aroid aty severe pain when the treatunents are so frequently repeated, as well as to avoid consideralle trauma. At first duily treatunents are given, but later the intervuls between sittings cun be increased, and the treatments should be eontinued over a period of several montlis. These putients onght to be warned thut reeurrences nre common, and that for this reasou they ure to return several times a year for dilatation.

\title{
PATHOLOGY AND BACTERIOLOGY
}

\author{
USOER THE CHATGE OF \\ OSIEAR KLOTZ, M.D., C.M.,

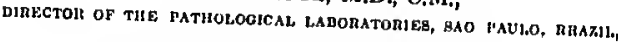 \\ AND \\ DE WAYNE G. RICHEY, B.S., M.D.,
}

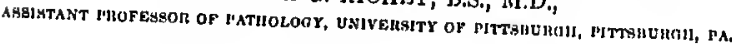

On the Claim that Some Typhoid-Paratyphoid Strains Survive the Milk Pasteurization.-KRuMwitede and Nonde (Jour. Infect. Dis., $1921,29,310)$ found that "there is no evidenee that bacilli of the typhoid and pnraty'ploid group even in sinull ummbers, will survive lieating to $60^{\circ} \mathrm{C}$., for twenty minutes," suggesting that the nppurent heat resistanee of the strains reported ly Twass (Jour. Infret. Dis., $1920,26,165)$ was due to the test inethod employed, namely, the use of cotton plugged flasks submerged to twice the deptlis of the milk. The authors used 27 typhoid eultures reently isolated from enrriers, 7 paratyphoid A, 12 paratyphoid $\mathrm{B}$ and 4 enteritidis eultures. Milk was sterilized and $100 \mathrm{ce}$ of it was infeeted with the eulturnl growth from two twenty-four hour agar slants suspended in salt solution. The baeterial suspension was added after the milk had reached $60^{\circ} \mathrm{C}$. rubber stoppers were inserted, the bottles vigorously shaken and completely sulmnerged in a water bath for fifteen ninutes. No baeteria survived a pastemrization period thus limited elosely to fifteen minutes
at $60^{\circ} \mathrm{C}$.

Antirabic Vaccination by Means of Desiccated Virus. - With slight modifications, D'Aunor (Jour. Infect. Dis., 1921, 29, 261) has employed a desiccated virus prepared according to Harris on aceount of its capability of production in a short time and preservation over indefinite periods. Full grown, healthy rabbits, averaging $2200 \mathrm{gin}$. were inoculated into the lateral ventricles after trephining with about $0.00-1 \mathrm{mg}$. 
of desiccated fixed virus in $I$ ce of sterile salt solution. The animul developed symptoms in six or seven days and when completc paresis had intervened, was killed by ether narcosis. The eord and brain were then rcmoved aseptically, and the mombranes were stripped off by needles. By grinding with salt solution, the nerve tissue was brought to a coarsc paste in a mortar. Carbon clioxide snow was then added with constant mixing and triturating until the mass had soliclificd. The inass was then plaeed in a meat grinder and kept at a temperature of ubout $12^{\circ} \mathrm{C}$. for a few hours, a small amount of $\mathrm{CO}_{2}$ again added and quick grinding aceomplished. The ground material was sprcad in a thin-layer and dried in a Scheibler desiceator at from 12 to $18^{\circ} \mathrm{C}$. With a vacuum of $2 \mathrm{~mm}$ of inereury, and plosphoric anhyelride, conplete desiecation was procurcel in about thirty-six hours. The dried virus was kept in large glass tubes in a dark place at from 10 to $15^{\circ} \mathrm{C}$. Control cultures of every bateh of virus were instituted. The unit or "minimnl infeetive dose" consists of the least annount of virus whieh within five days after preparation will cause paresis in a $2400 \mathrm{gm}$. rabbit on the seventh diay following intraccreloral injection. A virus containing 300 to 500 "ninimal infeetive loses" per mg. Wis readily produeed. It will lose $n o$ infectivity at $10^{\circ} \mathrm{C}$. for over two years and will last ubout three years ut $S$ to $12^{\circ} \mathrm{C}$. Adults were given 11 treatments of a total of 17,750 "minisuml infective doses" exeept in severe head injuries when 15 trentuments of a total of $25,750 \mathrm{~m}$. i. (l. werc administered subeutaneously. Only 1 lleath following complete trentment is reported in 1538 treited patients; 697 injuries by aninuls proved to be rabil. No paralysis or other untoward effects were eneonntered in the treated persons. The author feels that his results "on the basis of eompurison with similar reports on the use of the originul I'isteur dried cord inetlood, urgue for the effieneionsness and safety of the desicented virus method of prophyluetie antirabie rneeinition."

Botulism from Cheese.-Evidenee that botulism is widely disscminated in this eountry eun be found in the sporadie reports which lave appeared in reent years. Although it was onee thought that the botulinus toxin was produced only in the presenee of neat protein, Dickson was able to find it in the presenee of regetable protcin and now Nevin (Jour. Inf. Dis., 1921, 27, 226) reports the reeovery of both $\mathrm{B}$. botulinus and its toxin from home-inade cottage chese, after the ingestion of which three persons died. Two eases presented parilysis of the museles of deglutition, suffusion of the facc, ptosis, total dilatation and failnre of the pupils to react to light and paralysis of the muscles of the throat witl diffieulty of speech. The third patient was unable to swallow. There was no loss of consciousness or piresis of any other part of the borly. Subentuneous inoeulation of 3 ce of an emulsion of thic chcesc, after forty-eight hours' ineubation at $37^{\circ} \mathrm{C}$., killed gninen-pigs within thirty-six hours. By anac̈robic methods, a Grom-positive, inotilc, oval, sporebearing bacillus was isolated. No eapsule could be demonstratel, gelatin was liquefied slowly and milk coaguluteel in three days. Many carbohyedrutcs werc fermentel with the prorluetion of gas and the odlor of butyrie aeid. A potent toxin was produced on a peptone-free medimm. Guinei-pigs 